\title{
LEADER-FOLLOWER MODEL OF RECIPROCAL FDI AND INTERNATIONAL TRADE
}

In this paper we develop a two-country leader-follower model of reciprocal horizontal foreign direct investment (FDI) and international trade. First, we identify the conditions necessary for exporting and FDI depending on trade costs and the cost of foreign investment. Then, we demonstrate how various types of equilibriums may emerge in the short run and the long run depending on various combinations of the parameters of the model. Our model predicts that in the short run equilibriums the levels of output supplied by the home (foreign) firm to the home country market are bigger (smaller) compared to the long-run equilibriums. Therefore, the first mover advantage should be gradually disappearing over time. In addition, our model suggests several empirically testable hypotheses concerning the behavior of total output and prices in the industry after trade and investment liberalization.

Keywords: exporting, foreign direct investment, leader follower model, proximityconcentration trade off

JEL Classifications: F23

DOI: $10.15611 /$ aoe.2018.2.04

\section{INTRODUCTION}

One of the most frequently mentioned facts about globalization is the importance of multinational enterprises (MNEs). ${ }^{1}$ From the mid-1980s onwards, foreign direct investment (FDI) made by MNEs grew more rapidly than both world trade and world GDP. FDI originates predominantly from developed countries which have been at the same time the major recipients of FDI. Most FDI between these countries appears to be horizontal, as it was motivated by acquiring better access to markets in host countries. These real-world developments led to the emergence of the new theory of multinational enterprise (NTME) in the 1980s and 1990s which has been often viewed as an extension of the new trade theory literature. The NTME models usually assume some form of imperfect competition such as a simple Cournot oligopoly or monopolistic

\footnotetext{
* Department of Macroeconomics and International Trade Theory, Faculty of Economic Sciences, University of Warsaw.

${ }^{1}$ See, for example, Markusen (2002), Barba Navaretti and Venables (2004), Kleinert (2004) and Caves (2007) for the review of this literature.
} 
competition. This means that competing firms either take their actions simultaneously or simply neglect the actions of their rivals completely.

However, the international business literature documents a number of stories about first mover advantages and often provides recommendations concerning how a firm can establish a leadership position in the market by making the first move [Lieberman and Montgomery (1988)]. One of the most frequently cited examples of the first mover advantage is the canned soup industry. In this industry the contrast between the US and the UK is of particular interest as the same two firms used to dominate each of these markets [Sutton (1991)]. Initially, Campbell was the first entrant in the US market, while Heinz was the first entrant in the UK market. Later, Campbell entered the UK market while Heinz entered the UK market. Their roles in these two markets were exactly the opposite. While Campbell continued to be a leader in the US market and Heinz in the UK, Campbell was filling the same role in the UK market as Heinz in the US.

The main goal of this paper is to incorporate the role of the first mover advantage into the two-country model of horizontal FDI and international trade. Therefore, in contrast to the previous studies, in this paper we employ the Stackelberg (1934) leader-follower model to study the choice between exporting and FDI. First we identify the conditions necessary for exporting and FDI depending on the trade cost and the cost of foreign investment. Next, we demonstrate how particular Stackelberg equilibriums may emerge depending on various combinations of the key parameters of the model. Finally we show that in the long run, Stackelberg equilibriums will converge to the standard Cournot equilibriums.

The organization of this paper is as follows. Section 2 summarizes the relevant literature. Section 3 describes key assumptions and discusses the autarky equilibrium. Section 4 discusses the short-term open economy Stackelberg equilibriums. Section 5 compares these equilibriums to the longterm open economy Cournot equilibriums. Finally, Section 6 summarizes and provides directions for further studies.

\section{LITERATURE REVIEW}

There is an extensive literature on the relationship between exporting and FDI. In this literature several strands can be distinguished. First, the traditional neoclassical approach perceived FDI as a part of the portfolio theory of international capital flows. According to this approach there was no difference between FDI and portfolio investment. Differences in relative factor 
endowment combined with trade costs the differences or speciali-zation implied that there was no international factor price equalization and this motivated international capital flows. The early studies which examined the effects of tariffs on capital flows relied on some kind of a two-sector perfectly competitive factor-proportions general equilibrium framework, such as the Heckscher-Ohlin-Samuelson (HOS) model. The frequently cited examples of studies based on such frameworks include Mundell (1957), Hamada (1974) and Brecher and Diaz (1977). According to these studies, tariffs are directly responsible for the inflow of foreign capital. When a tariff is imposed on the imported good the domestic price of that good increases, assuming the absence of the Metzler paradox. As a result the capital rental rate in the domestic country goes up if the imported good is relatively capital-intensive, and this attracts capital from abroad. The capital inflow continues until the international differences in the return to capital are eliminated.

The traditional neoclassical approach was, however, criticized because of its reliance on the set of unrealistic assumptions, such as constant returns to scale (CRS) and perfect competition, which were not in line with the key industry-level stylized facts on FDI. For example, Markusen (2002, p. 6) notes that: i) "large differences exist across industries in the degree to which production and sales are accounted for by multinational firms", ii) "multinationals tend to be important in industries that a) have high levels of R\&D relative to sales, b) employ a large number of professional and technical workers as a percentage of their total workforces, c) produce new and/or technologically complex products, and d) have high levels of product differentiation and advertising", iii) "multinationals tend to be firms in which the value of the firms' intangible assets is large relative to its market value". Moreover, another problem was that in the neoclassical perfectly competitive constant returns approach firms were infinitely small and it was not possible to study directly the investment decisions that took place within the firm.

The next strand in the literature that attempted to model the firm's decision to produce abroad under increasing returns and imperfect competition was initiated in the early 1970s. In one of the earliest MNE theories assuming the existence of economies of scale, Aliber (1970) used the country size and the bias of exchange risk determination to explain the choice between exporting and FDI. Subsequent studies examined the choice between exporting and FDI by looking at the costs of exporting and FDI. In particular, Copithorne (1971), Horst (1971), and Hirsch (1976) attempted to model an exporting versus FDI decision of a monopolist using a partial 
equilibrium framework. $^{2}$ In this framework the firm faced a trade-off between proximity to the foreign market obtained by setting up production plants abroad, which allowed to economize on transportation and tariff costs, and concentration of production in the home country and serving foreign markets by exporting, which allowed to save on fixed costs of duplicating production capacity abroad. According to this framework, firms invest abroad in those industries in which the gains from avoiding trade costs outweigh the costs of setting up production plants abroad.

Finally, the last strand was the consequence of the development of the socalled New Trade Theory (NTT) in the late 1970s and early 1980s. This literature was based on the tools borrowed from the industrial organization literature which allowed to extend the neoclassical trade theory models based on not the realistic assumptions of perfect competition and constant returns to scale. The NTT models included more realistic market structures and embedded increasing returns to scale, and were usually assuming some form of imperfect competition such as monopolistic competition or a simple Cournot oligopoly. Although particular models within this strand differed with respect to assumptions concerning the market structure, the main prediction from this framework was very similar: firms are more likely to enter the foreign market via FDI rather than via exporting, the higher the trade costs and the lower fixed costs of entry and the size of economies of scale at the plant level compared to the firm level.

One of the earliest attempts to integrate multinational firms into the NTT was made by Krugman (1983). In contrast to the neoclassical approach, he followed the new concept of FDI in which no movement of physical or financial capital is necessary for FDI to take place. In order to study the possibility of multinational production, Krugman (1983) extended his previous general equilibrium models of international trade based on monopolistic competition (Krugman, 1979, 1980). He considered a simple two country framework with only one factor of production - labor - and assumed that the labor forces of both countries were equal. The perfect symmetry of the model's setup resulted in wage equalization across countries which greatly simplified the analysis. ${ }^{3}$ However, despite its analytical convenience, his framework did not gain much popularity in the

\footnotetext{
${ }^{2}$ See chapter 2 in Caves (2007) for a survey of the early literature on the choice between exporting and FDI.

${ }^{3}$ More general results for the asymmetric country case were obtained by Cieślik (2013) while more complex two factor models based on monopolistic competition were proposed by Markusen and Venables (1998) and Markusen (2002, ch.8). However, their models could not be solved analytically and the authors had to rely on numerical methods to study the properties of the equilibrium solutions.
} 
subsequent literature as it did not allow for studying the strategic interactions between competing firms, and his contribution has been mostly overlooked until recently. ${ }^{4}$

An alternative approach based on the partial equilibrium model of oligopolistic competition was developed by Markusen (1984). In his model the existence of firm-level scale economies was the driving force for FDI. In particular, two-plant firms had lower fixed costs than those of two single plants and that motivated multinational production. The original approach proposed by Markusen (1984) was extended in the number of his follow-up studies, including Horstmann and Markusen (1987, 1992), Markusen and Venables (1998, 2000), Markusen (2002, ch. 4; 2013), Bergstrand and Egger (2007, 2013), Markusen and Strand (2009), Markusen and Stähler (2011), and Chen et al. (2012). These models allowed for endogenous market structures and different forms of competition between firms within the partial as well as the general equilibrium frameworks. However, these studies usually assumed that entry decisions were made simultaneously in the first stage of the game. ${ }^{5}$

In particular, Horstmann and Markusen (1992) developed a model in which firms from home and foreign countries decided between: not entering; entering with one plant supplying both markets; and entering with two plants, each supplying local customers. Entry decisions in their model were made simultaneously in the first stage of the game. Three equilibriums were then possible: a classical duopoly Cournot equilibrium with two single-plant firms; a monopoly equilibrium with one plant in each country; and a duopoly equilibrium where both firms had plants in two countries. The first equilibrium emerged when plant specific costs were large relative to firm specific and trade costs. The second equilibrium emerged when trade and firm-specific costs were so high that two firms could not be profitable. Finally, the third equilibrium emerged with low plant specific costs.

\footnotetext{
4 The monopolistic competition framework was used by Helpman et al. (2004) who generalized Melitz's (2003) trade model with heterogeneous firms to study the role of firm productivity, in the choice between exporting and FDI. The development of this recent strand in the literature that focuses on the role of firm heterogeneity were summarized in several survey papers including Antràs and Yeaple (2015), Bernard et al. (2012) and Melitz and Redding (2015). The alternative approach to study the role of firm heterogeneity using the oligopoly framework was promoted by Cieślik and Ryan (2012) and Cieślik (2015a).

${ }^{5}$ The only exception is the two-period duopoly model presented in Chapter 4 of Markusen (2002) which builds on the earlier framework by Horstmann and Markusen (1987). In his model the multinational firm moves first while the potential entrant can choose to enter at the same time or wait until the next period.
} 
In contrast to the Horstmann and Markusen (1992) model, Smith (1987) and Motta (1992) provided an alternative framework to study the choice between exporting and FDI in which entry decisions were made sequentially. ${ }^{6}$ In the Smith-Motta framework the game unfolded as follows. In the first stage the home firm decided whether or not to establish a subsidiary in the foreign country. If it did, it incurred the fixed cost of building the production capacity; if it did not, it served the foreign market via exporting. By choosing to export, the firm incurred a constant per unit trade cost but saved the fixed cost of building the plant. The model assumed that the home firm's sales to the foreign market were profitable regardless of the method of supply chosen by the home firm. In the second stage the indigenous firm from the foreign country decided whether to enter the market or not. The local firm must have incurred the higher fixed cost to enter the market consisting of two separate components: the cost of finding out about the industry (i.e. developing a product, $R \& D$ ), which the multinational firm has already covered in its home country, and the fixed cost of building the plant which was the same as the cost of the multinational firm. Once both entry decisions were made the two firms engaged in Cournot competition to determine output quantities. The model assumed that the entry decisions were made taking into account their effects on the subsequent quantity equilibrium. Finally, it was assumed that marginal costs were constant and that markets were segmented.

Despite the fact that the entry decisions in the theoretical studies by Smith (1987) and Motta (1992) were made sequentially, they used a simple Cournot duopoly framework and did not consider the role of the first mover advantage. The recent extension of the Smith-Motta framework was provided by Cieślik (2015b) who studied the role of the first mover advantage in the choice between exporting and FDI using only the one country leader-follower framework proposed by Stackelberg (1934). In particular, he identified the conditions necessary for exporting and FDI depending on trade costs and the cost of foreign investment, and demonstrated that four possible types of equilibria: a monopoly FDI equilibrium, a monopoly exporting equilibrium, a leader-follower duopoly FDI equilibrium, and a leader-follower duopoly exporting equilibrium, may emerge in the short-run depending on various combinations of the key parameters of the model.

\footnotetext{
${ }^{6}$ A recent generalization of the Smith-Motta framework can be found in Cieślik (2016).
} 
Therefore this paper can be seen as an extension of the aforementioned studies. In particular, in this paper to study the role of the first mover advantage we use the two-country leader-follower in which a firm from the home country moves first instead of using the standard Cournot framework, to derive a broader set of conclusions.

\section{MAIN ASSUMPTIONS AND AUTARKY EQUILIBRIUM}

We assume that there is a single industry and two countries called Home $(\mathrm{H})$ and Foreign $(\mathrm{F})$ that are exactly the same in terms of production technologies and consumer preferences. In each country there is a single firm producing a homogenous product under increasing returns to scale which are modeled by assuming that the cost function of each firm is:

$$
T C(x)=F+G+c x,
$$

where: $F$ is the fixed cost of developing the product, $G$ is the fixed investment cost of entering the market (i.e. building a production plant there), $c$ is the constant marginal cost of production and $x$ is output. The firm and plant-specific fixed costs $F$ and $G$ are the sunk costs. It can be easily noted that the average cost of production declines with output as the fixed costs are spread over a larger number of units: $A C(x)=(F+G) / x+c$.

For simplicity, we also assume that if firms decide to implement FDI in the rival's market they have to pay extra fixed sunk costs of building additional plants which are exactly the same as the cost of entering their own markets $G$. It is further assumed that the marginal cost of production $c$ is exactly the same when firms produce their goods at home or in plants located in the rival's country. These assumptions are due to the fact that in the case of horizontal FDI, developed countries are very similar in terms of production technology and relative factor endowments. Moreover, assuming the equality of the fixed and marginal costs of production allows us to focus entirely on the role of the first mover advantage.

Exporting is an alternative to the high-fixed cost option of entering the rival's market via FDI. If the firm decides to export from its home plant it does not have to pay the fixed sunk cost $G$, but exporting is a high marginal cost option. We assume that in addition to the cost of production the firms have to pay the trade costs which consist of two components: transport cost $s$ and tariff $t$ which increase their marginal costs. The transport cost and the tariff are assumed to be exactly the same for both countries and exogenously given. 
Moreover, we assume that markets are segmented and the firms are not capacity constrained which means that the first mover advantage can be sustained only in the short-run. ${ }^{7}$

For simplicity, we assume that in each country there is an explicit simple linear inverse demand function that relates price $P$ to aggregate output $X$ supplied to the market:

$$
P(X)=a-X,
$$

where $a$ is the market size in the domestic country and $a>c$ in order to have positive sales.

As a useful benchmark, first we consider the case of the autarky equilibrium in each country when the firm from the other country cannot enter the rival's market. In this case, firms in both countries are the national monopolists. The profit function of each monopolist can be written as:

$$
\Pi^{M}=\left(a-X^{M}\right) X^{M}-c X^{M}-F-G .
$$

Hence, the monopoly output of each firm in each country equals:

$$
X^{M}=\frac{a-c}{2} .
$$

The autarky equilibrium price can be determined by substituting the monopoly output (14) into the inverse demand function (2) which yields:

$$
p^{M}=\frac{a+c}{2} .
$$

Substituting equilibrium solutions for output (4) and price (5) into the profit function (3) we obtain the equilibrium profit for the national monopolist:

$$
\Pi^{M}=\left(\frac{a-c}{2}\right)^{2}-F-G=\left(x^{M}\right)^{2}-F-G .
$$

The national monopolist is active in its market only if the following market participation constraint is satisfied:

\footnotetext{
${ }^{7}$ If the game between the leader and the follower is played repeatedly each firm will be following its best response function and the equilibriums will eventually converge to the standard Cournot outcomes in the long-run. Possible long-run equilibriums are discussed in a subsequent section of the paper.
} 


$$
F+G<\left(\frac{a-c}{2}\right)^{2}
$$

This condition means that the operating monopoly profit has to be bigger than the sunk fixed costs of the market entry.

\section{SHORT-RUN OPEN ECONOMY STACKELBERG DUOPOLY EQUILIBRIUMS}

In this section we discuss the short-run open economy Stackelberg duopoly equilibriums that may emerge as a result of trade and investment liberalization. The indigenous firms, which were previously the national monopolists, now become Stackelberg leaders in their own markets and followers in the rival's markets. Each firm has to determine the optimal rival's market entry strategy by choosing FDI or exporting. Irrespectively of the chosen strategy, the home firm has to compete with the foreign firm in each market. The home firm acts like the Stackelberg leader in the Home country market while in the Foreign country market it acts like the Stackelberg follower. Similarly, the foreign firm acts like the Stackelberg leader in the Foreign country market while in the Home country market it acts like the Stackelberg follower.

\section{Short-run FDI duopoly equilibrium}

Due to the symmetry of the setup, the roles of the home and foreign firms in each other's markets are exactly the opposite. Therefore, we can focus only on the market in the home country as the volume of output supplied to the foreign country market by the home firm will equal the volume of output supplied to the home country market by the foreign firm.

If the foreign firm enters the market in the host country via FDI the profit function of the home firm can be written as:

$$
\Pi_{H}^{F D I}=\left[a-\left(x_{F}^{F D I}+x_{H}^{F D I}\right)\right] x_{H}^{F D I}-c x_{H}^{F D I}-F-G .
$$

In a similar way we can write down the profit function of the foreign firm:

$$
\Pi_{F}^{F D I}=\left[a-\left(x_{F}^{F D I}+x_{H}^{F D I}\right)\right] x_{F}^{F D I}-c x_{F}^{F D I}-G .
$$

Using the first order condition for the foreign firm we can first calculate its reaction function given the output of the home firm: 


$$
x_{F}^{F D I}=\frac{a-c-x_{H}^{F D I}}{2} .
$$

Subsequently, we substitute this reaction function into the profit function of the home firm (8) and calculate its equilibrium level of output supplied to the home country market:

$$
x_{H}^{F D I}=\frac{a-c}{2} .
$$

We can note that the volume of output supplied by the home firm to the home country market when the foreign firm enters via FD is in the short-run exactly the same as in the case of the autarky equilibrium when the domestic firm was the national monopolist. Therefore, when the foreign firm does FDI the first-mover advantage allows the home firm to behave, at least in the short-run, exactly as it was the national monopolist.

Substituting the equilibrium level of output for the home firm into the reaction function of the foreign firm (10) yields its equilibrium level of output:

$$
x_{F}^{F D I}=\frac{a-c}{4} .
$$

We can note that the equilibrium level of output supplied to the home country market by the foreign firm when it makes FDI equals exactly half of the output supplied by the home firm.

The total equilibrium level of output supplied to the home country market when the foreign firm makes FDI is the sum of outputs (11)-(12) supplied jointly by the home and foreign firms:

$$
X^{F D I}=x_{H}^{F D I}+x_{F}^{F D I}=\frac{3(a-c)}{4}>X^{M} .
$$

It can be noted that despite the fact that the home firm enjoys the firstmover advantage and behaves exactly like the national monopolist, the total level of output supplied to the market is now bigger compared to the autarky equilibrium due to the positive output response of the foreign firm.

The equilibrium price in the home country market can be determined by substituting the sum of output (13) into the inverse demand function (2) which yields:

$$
p^{F D I}=\frac{a+3 c}{4}<p^{M}=\frac{a+c}{2} .
$$


Using our solutions for the equilibrium quantities (11)-(12) and price (14) the profits for the home and foreign firms, respectively, made in the home country market can be written as:

$$
\begin{gathered}
\Pi_{H}^{F D I}=2\left(\frac{a-c}{4}\right)^{2}-F-G, \\
\Pi_{F}^{F D I}=\left(\frac{a-c}{4}\right)^{2}-G .
\end{gathered}
$$

It can be noted that the operating profit of the home firm is lower compared to the national monopoly profit as now it has to compete with the foreign firm. In the leader-follower FDI duopoly equilibrium, the operating profit of the home firm is twice as big as the profit of the foreign firm. Similarly, the market share of the domestic firm is twice as high as the market share of the foreign firm.

To ensure that both firms are active in the home-country market we need to impose the market participation constraints stating that both firms have nonnegative levels of equilibrium profits. These conditions require that operating profits in the home country market must be bigger than the sunk fixed costs.

The participation constraint for the home firm requires that

$$
F+G<2\left(\frac{a-c}{4}\right)^{2}
$$

The participation constraint for the foreign firm requires that

$$
G<\left(\frac{a-c}{4}\right)^{2} .
$$

The home firm earns a higher operation profit and has to pay the higher fixed cost while the foreign firm earns a lower operating profit but has to pay a lower fixed cost. If both (17) and (18) are met, then both firms have nonnegative profits and supply positive amounts of output to the home country market.

\section{Short-run exporting duopoly equilibrium}

If the foreign firm decides to enter the home country market via exporting we also have the Stackelberg duopoly problem in which the home firm makes the first move. In this case the profit function for the home firm can be written as: 


$$
\Pi_{H}^{E X}=\left[a-\left(x_{F}^{E X}+x_{H}^{E X}\right)\right] x_{H}^{E X}-c x_{H}^{E X}-F-G .
$$

Similarly, the profit function of the foreign firm can be written as:

$$
\Pi_{F}^{E X}=\left[a-\left(x_{F}^{E X}+x_{H}^{E X}\right)\right] x_{F}^{E X}-(c+s+t) x_{F}^{E X} .
$$

For the foreign firm, exporting to the home country market from the production facility located in the Foreign country implies a high marginal cost option due to the existence of transport costs $s$ and tariffs $t$. Using the first order condition for the foreign firm we can first calculate its reaction function given the output of the home firm:

$$
x_{F}^{E X}=\frac{a-c-s-t-x_{H}^{E X}}{2} .
$$

Subsequently, we substitute this reaction function into the profit function of the home firm (19) and calculate its equilibrium level of output supplied to the home country market:

$$
x_{H}^{E X}=\frac{a-c+s+t}{2} .
$$

Substituting the equilibrium level of output of the home firm into the reaction function of the foreign firm (21) yields its equilibrium level of output:

$$
x_{F}^{E X}=\frac{a-c-3(s+t)}{4} .
$$

We can note that compared to FDI solutions now the equilibrium levels of output contain the transport cost and the tariff. As a result, the volume of output supplied by the home firm to the home country market is more than two times bigger than the volume of output supplied by the foreign firm. Only in the extreme case when trade is completely free, i.e. $s+t=0$, the output levels of both firms are exactly the same as in the case when the foreign firm served the host country market via FDI.

The total equilibrium level of output supplied to the home country market is the sum of outputs (22)-(23) supplied jointly by the home and foreign firms that equals:

$$
X^{E X}=x_{H}^{E X}+x_{F}^{E X}=\frac{3(a-c)-(s+t)}{4}<X^{F D I} .
$$


It can be noted that the equilibrium level of total output supplied to the home market when the foreign firm enters this market via exporting is smaller compared to the equilibrium level of output in the case when it enters via FDI (13) due to the inefficiencies associated with the existence of the transport cost and the tariff.

The equilibrium price in the home country market can be determined by substituting the sum of output (24) into the inverse demand function (2) which yields:

$$
p^{E X}=\frac{a+3 c+s+t}{4}>p^{F D I} .
$$

It can be noted that the price in the leader-follower exporting equilibrium will always be higher compared to the leader-follower FDI equilibrium due to the technical inefficiency associated with the existence of the trade costs. Using our solutions for the equilibrium quantities (22)-(23) and the equilibrium price (25) we can determine the equilibrium profits made in the home country for the home and foreign firms, respectively:

$$
\begin{gathered}
\Pi_{H}^{E X}=2\left(\frac{a-c+s+t}{4}\right)^{2}-F-G>\Pi_{H}^{F D I}, \\
\Pi_{F}^{E X}=\left(\frac{a-c-3(s+t)}{4}\right)^{2} .
\end{gathered}
$$

To ensure both firms are active in the home country market we must impose market participation constraints on the home and foreign firms stating that they must have non-negative levels of profits. The participation constraint for the home firm requires that:

$$
F+G<2\left(\frac{a-c+s+t}{4}\right)^{2}
$$

Similarly, the participation constraint for the foreign firm requires that:

$$
3(s+t)<a-c .
$$

We can note that it is easier for the home firm to satisfy the participation constraint (28) compared to (17) as now it has a higher operating profit compared to the previous case when the foreign firm entered the home country market via FDI. If both (28) and (29) are satisfied, then both firms have non-negative profits and supply positive amounts of output to the home country market. 
It can also be noted that for the home firm it is always better if the foreign firm enters the home country market via exporting rather than via FDI. The home firm's profit is higher when the foreign firm exports than when it enters via FDI for two reasons: i) the home firm's larger sales, and ii) a higher equilibrium price. However, for the foreign firm such a simple generalization cannot be made. Although the operating profit associated with FDI is higher than the exporting profit, the fixed cost of investment G can make the foreign firm's overall profit of FDI lower than the profit from exporting. Hence, whether the profit from exporting is bigger or smaller compared to the profit from FDI for the foreign firm depends on the interplay between the trade and investment costs (i.e. $s+t$ and $G$ ).

To analyze the short-run tradeoff between FDI and exporting we compare the profits of the foreign firm from the FDI duopoly (16) and exporting duopoly (27). The profits of the foreign firm from the exporting duopoly and FDI duopoly are equal when:

$$
G=\frac{6(a-c)(s+t)-9(s+t)^{2}}{16}
$$

If $\mathrm{G}$ is bigger (smaller) than the threshold value (30) then exporting (FDI) is the preferred entry strategy for the foreign firm. Moreover, FDI can always be preferred to exporting for certain combinations of model parameters such as the high trade cost and the low fixed cost of investment. Similarly, exporting can always be preferred to FDI for certain combinations of model parameters such as the low trade cost and the high fixed cost of investment.

Our short-term findings can be summarized in Result 1:

RESULT 1. The short-run Stackelberg FDI equilibrium occurs when $F+G<2\left(\frac{a-c}{4}\right)^{2}$ and $G<\left(\frac{a-c}{4}\right)^{2}$ if: $\quad$ i) $3(s+t)<a-c \quad$ and
$G<\frac{6(a-c)(s+t)-9(s+t)^{2}}{16}$, or ii) $3(s+t)>a-c$. The short-run Stackelberg exporting equilibrium occurs when $F+G<2\left(\frac{a-c}{4}\right)^{2}$ and $3(s+t)<a-c$ if: i) $G<2\left(\frac{a-c}{4}\right)^{2}$ and $G>\frac{6(a-c)(s+t)-9(s+t)^{2}}{16}$ or ii) $G>\left(\frac{a-c}{4}\right)^{2}$. 


\section{LONG-RUN OPEN ECONOMY COURNOT DUOPOLY EQUILIBRIUMS}

It must be noted that the leader-follower equilibriums discussed in the previous section represent only the short-run equilibriums which are not stable in a multi-period game. If the game between the home and the foreign firms is played repeatedly each firm will be following its best response function and the equilibriums will eventually converge to the standard Cournot outcomes in the long-run. ${ }^{8}$ Therefore, in this section we discuss the properties of equilibriums that emerge in the long-run and compare them to the short-run Stackelberg equilibriums discussed in the previous section.

\section{Long-run FDI duopoly equilibrium}

The levels of output supplied by the home and foreign firms to the home country market when the foreign firm does FDI can be determined using the first order conditions for both firms to obtain, respectively:

$$
\begin{aligned}
& x_{H}^{F D I}=\frac{a-c}{3}, \\
& x_{F}^{F D I}=\frac{a-c}{3} .
\end{aligned}
$$

We can note that the long-run volumes of output supplied by the home and foreign firms to the Home country market when the foreign firm enters via FDI are exactly the same. The output supplied by the home firm is now smaller compared to its short-run equilibrium level of output while the output supplied by the foreign firm is bigger. This means that the initial first-mover advantage the home firm enjoys in the home country market is eliminated over time and eventually the market is split equally between the firms.

The total long-run equilibrium level of output supplied to the Home country market is the sum of outputs (31)-(32) supplied jointly by the home and foreign firms which can be written as:

$$
X^{F D I}=x_{H}^{F D I}+x_{F}^{F D I}=\frac{2(a-c)}{3} .
$$

\footnotetext{
${ }^{8}$ In the industrial organization literature the only way for the leader firm to remain in the firstmover advantage position in the long-run is to make a pre-commitment by the choice of production capacity before the Stackelberg game is played. This pre-commitment can prevent the game from coming back to the standard Cournot equilibrium in the long-run. This issue deserves more attention in future studies.
} 
It can be noted that the total long-run level of output supplied to the home country market is smaller compared to the previously discussed total shortrun equilibrium level of output (13) but still bigger compared to the national monopoly level (4). As the long-run equilibrium level of output is smaller the long-run equilibrium price is higher compared to the short-run equilibrium price (14) but still lower compared to the national monopoly level (5).

The equilibrium price in the home country market can be determined by substituting the sum of output (33) into the inverse demand function (2) to obtain:

$$
p^{F D I}=\frac{a+2 c}{3} .
$$

Using our solutions for the equilibrium quantities (31)-(32) and price (34), the total profits for the home and foreign firms, respectively, can be written as:

$$
\begin{gathered}
\Pi_{H}^{F D I}=\left(\frac{a-c}{3}\right)^{2}-F-G, \\
\Pi_{F}^{F D I}=\left(\frac{a-c}{3}\right)^{2}-G,
\end{gathered}
$$

It can be noted that the long-run profit of the home firm made in the home country market is lower compared to the short-run profit (15), while the long-run profit of the foreign firm is higher compared to the short-run profit (16).

To ensure that both firms are active in the home country market we need to impose market participation constraints stating that both firms have nonnegative long-run levels of equilibrium profits. These conditions require that operating profits in the home country market must be bigger than the fixed costs. The participation constraint for the home firm requires that

$$
F+G<\left(\frac{a-c}{3}\right)^{2} .
$$

The participation constraint for the foreign firm requires that

$$
G<\left(\frac{a-c}{3}\right)^{2} .
$$


It can be noted that it is easier for the foreign firm to satisfy the participation constraint in the long-run than in the short-run as the long-run operating profit from FDI is higher than the short run operating profit, while the opposite conclusion holds for the home firm. Moreover, if the home firm is active in the home country market then also the foreign firm is active, because when (37) is satisfied, then (38) is satisfied as well.

\section{Long-run exporting duopoly equilibrium}

The levels of output supplied by the home and foreign firms to the home country market when the foreign firm exports can be determined using the first order conditions for both firms to obtain, respectively:

$$
\begin{gathered}
x_{H}^{E X}=\frac{a-c+s+t}{3}, \\
x_{F}^{E X}=\frac{a-c-2(s+t)}{3} .
\end{gathered}
$$

We can note that compared to long-run FDI, equilibrium levels of output supplied by the home and foreign firms to the home country market are not the same. In particular, the home firm's output is bigger than the foreign firm's output due to the existence of the trade costs. Moreover, it can also be noted the output supplied by the home firm is now smaller compared to the short-run level of output, while the output supplied by the foreign firm is bigger. This means that the initial first-mover advantage the home firm enjoys over the foreign firm in the home country market disappears over time. However, in this case the firms do not have equal shares in the Home country market unless trade is completely free, i.e. $s+t=0$.

The total long-run equilibrium level of output supplied to the home country market is the sum of outputs (39)-(40) supplied jointly by the home and foreign firms that equals:

$$
X^{E X}=x_{H}^{E X}+x_{F}^{E X}=\frac{2(a-c)-(s+t)}{3} .
$$

We can note that the long-run equilibrium level of total output supplied to the home country market when the foreign firm enters this market via exporting is smaller compared to compared to the equilibrium level of output in the case when it enters via FDI (33). Moreover, it can be noted that the total long-run level of output supplied to the host country market is now smaller compared to the previously discussed total short-run equilibrium level of output (23), but still bigger compared to the national monopoly level 
(4). As the long-run equilibrium level of output is smaller the long-run equilibrium price is higher compared to the short-run equilibrium price (25) but still lower compared to the national monopoly level (5).

The equilibrium price in the home country market can be determined by substituting the sum of output (41) into the inverse demand function (2) which yields:

$$
p^{E X}=\frac{a+2 c+s+t}{3} .
$$

It can be noted that the price in the long-run exporting Cournot equilibrium is higher compared to the long-run FDI Cournot equilibrium price (34) due to the technical inefficiency associated with the existence of the trade cost. Using our solutions for the equilibrium quantities (39)-(40) and the equilibrium price (42) we can determine the equilibrium profits for the home and foreign firms, respectively:

$$
\begin{gathered}
\Pi_{H}^{E X}=\left(\frac{a-c+s+t}{3}\right)^{2}-F-G, \\
\Pi_{F}^{E X}=\left(\frac{a-c-2(s+t)}{3}\right)^{2} .
\end{gathered}
$$

To ensure both firms are active in the home country market we must impose market participation constraints on the home and foreign firms stating that they must have non-negative levels of profits.

The participation constraint for the home firm requires that:

$$
F+G<\left(\frac{a-c+s+t}{3}\right)^{2} .
$$

Similarly, the participation constraint for the foreign firm requires that:

$$
2(s+t)<a-c .
$$

It can be noted that it is easier for the foreign firm to satisfy the participation constraint in the long-run than in the short-run as the long-run operating profit from exporting is higher than the short-run operating profit, while the opposite conclusion holds for the home firm. If both (45) and (46) are satisfied, then both firms have non-negative profits and supply positive amounts of output to the home country market. Moreover, it can be noted that also in the long-run it is always better for the home firm if the foreign firm enters the home country market via exporting rather than via FDI. 
However, similar to the short-run case, for the foreign firm such a simple generalization cannot be made as whether the profit from exporting is bigger or smaller compared to the profit from FDI for the foreign firm depends on the interplay between the trade and investment costs $(s+t$ and $G)$. To study the long-run tradeoff between FDI and exporting we compare the profits of the foreign firm from FDI duopoly (36) and the exporting duopoly (44). The profits of the foreign firm from the exporting duopoly and the FDI duopoly are equal when:

$$
G=\frac{4(a-c)(s+t)-4(s+t)^{2}}{9} .
$$

If $G$ is bigger (smaller) than the threshold value (47) then exporting (FDI) is the preferred entry strategy for the foreign firm. It can be noted that the long-run threshold value of the fixed cost (47) is bigger than the short-run value (30). This means that in the long-run, FDI is more attractive for the foreign firm compared to exporting.

Our long-term findings can be summarized in Result 2:

RESULT 2. The long-run Cournot FDI equilibrium occurs when $F+G<\left(\frac{a-c}{3}\right)^{2}$ and $G<\left(\frac{a-c}{3}\right)^{2} \quad$ if $\quad: \quad$ i) $\quad 2(s+t)<a-c \quad$ and $G<\frac{4(a-c)(s+t)-4(s+t)^{2}}{9}$, and ii) $2(s+t)>a-c$. The long-run Cournot exporting equilibrium occurs when $F+G<\left(\frac{a-c}{3}\right)^{2}$ and $2(s+t)<a-c$ if: i) $G<\left(\frac{a-c}{3}\right)^{2}$ and $G>\frac{4(a-c)(s+t)-4(s+t)^{2}}{9}$ or ii) $G>\left(\frac{a-c}{3}\right)^{2}$.

\section{CONCLUSION}

In this paper we developed a two-country leader-follower model of reciprocal FDI and international trade. First, we identified the conditions necessary for exporting and FDI, depending on the trade costs and the cost of foreign direct investment. Then, we demonstrated how exporting and FDI equilibriums may emerge depending on various combinations of the parameters of the model.

The short-run Stackelberg duopoly equilibriums seem to be in line with the observed patterns described in the international business literature 
documenting the importance of the first mover advantage. In both types of the short-run equilibriums the levels of output supplied by the domestic (foreign) firm to the home country market were bigger (smaller) compared to the long-run equilibriums. Therefore, the importance of the first mover advantage should be diminishing over time. In particular, it should be expected that the share of the domestic firm in the Home country market should be falling, while the share of the foreign firm should be increasing. This hypothesis deserves more attention in future empirical studies.

The model also suggests several other empirically testable hypotheses concerning the time pattern of total output and price in the industry following trade and investment liberalization. In particular, right after trade and investment liberalization the total volume of output will expand rapidly as the domestic incumbent confronted with foreign competition in the shortrun will be producing higher levels of output compared to the long-run levels. In the long run the domestic incumbent will contract and the total level of output in the industry will fall as the output reduction of the incumbent will not be fully compensated by the increase in output supplied by the foreign firm. However, in the long run the output level in the industry will still be higher compared to the pre-liberalization level. As a result, it should be expected that the price level in the industry right after trade and investment will fall and later it will increase, however, in the long-run it will be below the pre-liberalization level. Therefore, trade and investment liberalization can be regarded as effective instruments of an anti-trust policy.

\section{REFERENCES}

Antràs, P., Yeaple, S. R., Multinational Firms and the Structure of International Trade [in:] Helpman E., Rogoff K. and Gopinath G. (eds.), Handbook of International Economics, vol. 4, pp. 55-130. Elsevier, Amsterdam, 2015.

Barba Navaretti, G., Venables, A., Multinational Firms in the World Economy. Princeton University Press, Princeton, 2004.

Bernard, A. B., Jensen, J. B., Redding, S. J., Schott, P. K., The Empirics of Firm Heterogeneity and International Trade, "Annual Review of Economics" 4, pp. 283-313, 2012.

Bergstrand, J. H., Egger, P., A Knowledge and Physical Capital Model of International Trade Flows, Foreign Direct Investment and Multinational Enterprises, "Journal of International Economics" 73(2), pp. 278-308, 2007.

Bergstrand, J. H., Egger, P., Shouldn't Physical Capital also Matter for Multinational Enterprise Activity?, "Review of International Economics" 21(5), pp. 945-965, 2013.

Brander, J., Intra-industry Trade in Identical Commodities, "Journal of International Economics" 11, pp. 1-14, 1981. 
Brander, J., Krugman, P., A 'Reciprocal Dumping' Model of International Trade, “Journal of International Economics" 15, pp. 313-321, 1983.

Caves, R., Multinational Enterprise and Economic Analysis, $3^{\text {rd }}$ edition. Cambridge University Press, Cambridge, 2007.

Chen, Y., Horstmann, I. J., Markusen, J. R., Physical Capital, Knowledge Capital, and the Choice between FDI and Outsourcing, "Canadian Journal of Economics" 45(1), pp. 1-15, 2012.

Cieślik, A., Horizontally Integrated MNE and Plant Heterogeneity, "Bank i Kredyt" 44(6), pp. 605-622, 2013.

Cieślik, A., Imperfect Competition, Productivity Differences and Proximity-Concentration Trade-offs, "Ekonomia" 40, pp. 7-30, 2015a.

Cieślik, A., North-North FDI, Exporting and the First Mover Advantage, "Bank i Kredyt", 46(2), pp. 109-128, 2015b.

Cieślik, A., Exports versus FDI in Smith-Motta Framework, "Equilibrium. Quarterly Journal of Economics and Economic Policy", 11(2), pp. 189-218, 2016.

Cieślik, A., Ryan, M., Productivity Differences and Foreign Market Entry in an Oligopolistic Industry, "Open Economies Review” 23(3), pp. 531-557, 2012.

Greenaway, D., Kneller, R., Firm Heterogeneity, Exporting and Foreign Direct Investment, "Economic Journal" 117 (517), pp. 134-161, 2007.

Girma, S., Kneller, R., Pisu, M., Exports versus FDI: An Empirical Test, "Review of World Economics" 141(2), pp. 193-218, 2005.

Helpman, E., Melitz, M., Yeaple, S., Export versus FDI with Heterogeneous Firms, “American Economic Review” 94, pp. 300-316, 2004.

Horstmann, I., Markusen, J., Strategic Investments and the Development of Multinationals, "International Economic Review" 28, pp. 109-121, 1987.

Horstmann, I., Markusen, J., Endogenous Market Structure in International Trade, "Journal of International Economics" 32, pp. 109-129, 1992.

Kleinert, J., The Role of Multinational Enterprises in Globalization. Springer, BerlinHeidelberg, 2004.

Krugman, P., Increasing Returns, Monopolistic Competition, and International Trade, "Journal of International Economics", vol. 9, no. 4, pp. 469-479, 1979.

Krugman, P., Scale Economies, Product Differentiation and the Pattern of Trade, "American Economic Review" 70(5), pp. 950-959, 1980.

Krugman, P., The 'New Theories' of International Trade and Multinational Enterprise [in:] Audretsch, D. B., Kindleberger, Ch. P., (eds.), The Multinational Corporation in the 1980s. MIT Press, Cambridge, MA, 1983.

Lieberman, M. B., Montgomery, D. B., First Mover Advantages, "Strategic Management Journal" 19, pp. 1111-1125, 1998.

Markusen, J. R., Multinationals, Multi-plant Economies and the Gains From Trade, "Journal of International Economics", vol. 16, no. 3-4, pp. 205-226, 1984.

Markusen, J., Multinational Firms and the Theory of International Trade. MIT Press, Cambridge, MA, 2002.

Markusen, J. R., Multinational firms [in:] Bernhofen, D., Falvey, R., Greenaway, D., Kreickemeier, U. (eds.), Palgrave Handbook of International Trade. Palgrave Macmillan, 2013. 
Markusen, J. R., Stähler, F., Endogenous Market Structure and Foreign Market Entry, "Review of World Economics" 147(2), pp. 195-215, 2011.

Markusen, J. R., Strand, B., Adapting the Knowledge-capital Model of the Multinational Enterprise to Trade and Investment in Business Services, "World Economy" 32(1), pp. 6-29, 2009.

Markusen, J. R., Venables, A. J., Multinational Firms and the New Trade Theory, "Journal of International Economics", vol. 46, no. 2, pp. 183-203, 1998.

Markusen, J. R., Venables, A. J., The Theory of Endowment, Intra-Industry and Multinational Trade, "Journal of International Economics", vol. 52, no. 2, pp. 209-234, 2000.

Melitz, M., The Impact of Trade on Intra-Industry Reallocations and Aggregate Industry Productivity, "Econometrica" 71, pp. 1695-1725, 2003.

Melitz, M. J., Redding, S. J., Heterogeneous Firms and Trade [in:] Helpman, E., Rogoff, K., Gopinath, G. (eds.), Handbook of International Economics, vol. 4, pp. 1-54. Elsevier, Amsterdam, 2015.

Motta, M., Multinational Firms and the Tariff Jumping Argument, "European Economic Review" 36, pp. 1557-1571, 1992.

Smith, A., Strategic Investment, Multinational Corporations and Trade Policy, "European Economic Review" 31, pp. 89-96, 1987.

Stackelberg, H., von, Marktform und Gleichgewicht. Julius Springer, Vienna, 1934.

Sutton, J., Sunk Costs and Market Structure. MIT Press, Cambridge, MA, 1991.

Received: February 2015 